\title{
Research on the Integration Development of Marxism in China and the \\ Modernization of Chinese National Spirit
}

\author{
Yue Zhang
}

Nanjing Institute of Mechatronic Technology, Jiangsu, Nanjing, China, 210000

\begin{abstract}
Keywords: Marxism in China; Chinese National Spirit; Modernization; Communion and Development
\end{abstract}

\begin{abstract}
Marxism in China belongs to the category of international communist theory and the eternal proposition in the development of Marxism. In the report of the 17th National Congress of the Communist Party of China, Marxism only combined with its own national conditions and with the people in the development of the times breathe and destroys in order to ensure its tenacious vitality, creativity and appeal. Therefore, the question of Marxism in China must adhere to the Marxist standpoint and viewpoint, and use the Marxist method to grasp the global development trend accurately, make accurate positioning and judgment on the basic national conditions of the primary stage of socialism in China, and profoundly analyze the reality of reform and development situation, sum up experience, continuous innovation. The spirit of the Chinese nation is the soul element in the construction of socialist modernization in our country. It provides value orientation and spiritual power for the development of the Chinese nation. Therefore, it is of great practical significance to realize the communion of Marxism with the modernization of Chinese national spirit.
\end{abstract}

\section{Introduction}

The great practice of Marxism in China led by the Communist Party of China has profoundly changed the course of Chinese historical development. At the primary stage of socialism, the localization of Marxism in China is still an inevitable choice for building socialism with Chinese characteristics. Under the impetus of the development of the Communist Party of China, the localization of Marxism in China and the spirit of the Chinese nation took part in the process of the formation of Marxist tradition, so the two were inseparable and closely related. It is precisely in this interactive relationship between the two-way construction and the value orientation of both is to realize the fundamental interests of the people, all to achieve the great rejuvenation of the Chinese nation as the goal, so the Marxism in China and the Chinese national spirit positive interaction embodies the Chinese nation's external and internal exploration and efforts.

\section{The Connotation of the Marxism in China and the Modernization of Chinese National Spirit}

The Connotation of Marxism in China. Marxism in China is the name of Marxism and the basic principles of Chinese actual situation of the organic combination of Marxist basic principles and the reality of China, Chinese history, Chinese culture, in the development process of Chinese Marxism nationalization, reflecting the unique characteristics of Chinese, with "Chinese people loved by the Chinese style and Chinese style." In particular, the scientific connotation of Marxism in China can be summarized as follows: First, in the process of Chinese revolution, development and 
construction, economic reform, the application of Marxist theory to solve practical problems with Chinese characteristics; Secondly, in the Chinese revolution, construction and economic reform using Marxist theory to the practical experience and historical experience of the theoretical summary; Finally, the so-called Marxism in China is about Marxism rooted into Chinese outstanding traditional culture.

The Connotation of the National Spirit. The so-called national spirit which contains the national consciousness, national culture, national customs, national beliefs, ethnic and religious and national values and other rich content, these common qualities in a nation's long-term development process precipitated, different from other peoples unique quality is the national traditional culture to maintain, coordinate, guide, promote the survival and development of the nation's soul, it can be said that the national spirit represents the whole nation's vitality, creativity and cohesion. The basic characteristics of the modernization of the Chinese national spirit belong to the category of cultural modernization, specifically in the following aspects: First, the modernization of the Chinese national spirit based on political and economic modernization, not only on the political and economic development have far-reaching impact secondly, relative to the economic and political modernization, the national spirit of modernization has a deeper meaning, its start is relatively late, from the traditional to the modern transformation process is more complex; again the result of the modernization of the national spirit is manifested in the specific national culture. Its function is embodied in all levels of the practice of the national society. In the different social and historical environments, the national spirit modernization embodies the characteristics of unity and diversity.

\section{The Necessity of the Combination of Marxism in China and the Chinese National Spirit}

On the one hand, Marxism in China can further promote and cultivate the spirit of the Chinese nation. Chinese invasion of China since the Opium War has been in a state of backwardness. The Western powers invaded China, not only seriously affected Chinese political and economic development, but also the invasion of Western culture had a strong impact and challenge on Chinese traditional culture. It said that the Chinese nation, the country is facing a survival crisis. Although many patriots in order to save the country, self-help put forward a lot of solutions to resolve the crisis, but cannot fundamentally save the Chinese nation in distress. Since the great scientific theory of Marxism has been born and transferred to China, it has brought new hope for the development of the Chinese nation. With its practice in China and the continuous development of China, Marxism has fundamentally saved China to provide a strong theoretical guidance for Chinese development. In the process of developing socialism with Chinese characteristics, the two theoretical achievements of Marxism in China still play an important ideological guiding role. The spirit of the Chinese nation is constantly enriching the spiritual elements of the times in different backgrounds and keeping the national spirit to the greatest extent the vitality of the national spirit and the full play of the role.

On the other hand, the promotion and cultivation of the Chinese national spirit in turn promote the development of Marxism in China. A nation in order to stand in the world of national forest, its national spirit is the great cause of national development of the soul, the core. In the process of developing socialism with Chinese characteristics, to realize the localization of Marxism in China, we need to provide support and impetus to the Chinese nation spirit as a catalyst. The development of Marxism in China should be based on the practice of the masses of the people, and the history of Chinese development also proves that the nation is prosperous and the prosperity of the country cannot be separated from the cohesion and centripetal force of the masses. Therefore, the cohesion of the masses of the people Development has a direct impact, the higher the overall quality of the 
people, the stronger the centripetal force, the development of Marxism in China, the more powerful. It can be seen that the development of Marxism in China and the development of the spirit of the Chinese nation are interrelated and mutually reinforcing. Therefore, strengthening the benign interaction between the two is an important measure to promote the revival of the Chinese nation.

\section{The Development Strategy of Marxist Sinicization and the Chinese National Spirit Modernization}

Achieve the Unity of Promoting the Chinese National Spirit and the Absorption of Foreign Outstanding Culture. In fact, the spirit of the Chinese nation has been in a dynamic development process, which belongs to the historical concept of history, the changes in the times will inevitably lead to changes in national spirit, national spirit can better adapt to the modern environment, so different times, the spirit of the Chinese nation habits, cultural psychology, etc. will also occur in varying degrees of change. With the continuous development of science and technology, information technology and human civilization, cultural exchanges around the world not only faster and faster, its scale is also growing, our national cultural construction not only to inherit the traditional, innovative, but also pay close attention to the development trend of world culture, face the influence and penetration of various spiritual and cultural forces in the world today, open the open pattern of all-round, multi-level and wide field, absorb the essence of foreign excellent culture, realize the essence of the Chinese nation and the unity of the world, pay attention to the openness of traditional culture, and truly "national, world". In the world, the spiritual civilization of the Chinese nation is unique, but it also belongs to the part of the world's spiritual civilization, in the process of absorbing foreign culture should also focus on their own cultural characteristics of the combination, after screening, filtering, digestion, absorbed into the use, for the development of traditional Chinese culture into the organ reported vitality. World civilization is mutual influence, interrelated, such as the American people's innovative spirit, the Japanese people's team spirit, the German people's rigorous, etc., can be used for me to make up for their own cultural deficiencies, learn from other peoples of the excellent spirit of development own oneself.

Promote the Creative Change from Chinese National Spirit Achieve from the Tradition to the Modern. Multi-level and multi-dimensional interpretation of Marxist theory of Chinese can be seen, based on the cultural perspective of the perspective of Marxism in China is the representative of modern advanced culture, and the deep connotation of the Chinese national spirit blend can further optimize the spirit of the Chinese nation to promote its creative transformation in the development, and in this process will be Marxism into the spirit of the Chinese nation, the two blend with each other, to promote China to the modern history of the new culture forward. Although Marxism was born in the western historical and cultural background, but its concern is the complete liberation of mankind and comprehensive development, both recognize the advanced nature of Western culture, but also to criticize the evil of capitalism, to some extent Marxism is the transcendence of the modernity of capitalism, so it has a key role that cannot be replaced by other theories. To determine the guiding ideology of Marxism can better break the development of modern Chinese culture, "power and founding" stalemate, both to promote the modern transformation of Chinese culture, but also to some extent resist the invasion of Western dross culture, making the Chinese national spirit modernization into the overall advancement stage, in order to achieve the modernization of China with the road to lay a solid spiritual foundation.

Carry Forward the Integration of National Spirit and Culture under the Guidance of the Socialist Core Value System. In the course of the historical development of the five thousand years of the Chinese nation, the excellent traditional culture has always been the core soul of the spiritual 
activities of the Chinese nation. As the master of traditional Chinese culture and the spirit of the Chinese nation, the Chinese Communist Party has always played the leading role of culture, the struggle for strength as an important means of development, makes the cultural work in the historical revolution, economic construction and reform and opening up the role of increasingly prominent, and promote the development of our party history. Of course, in certain circumstances, the organizational part of the superstructure will have a negative effect on the economic base, and in the course of our party's ruling, due to the lack of cultural construction caused by moral anomie phenomenon is not uncommon, it will not only directly damage our party in the people Image, increase the social disharmony factors, intensify social contradictions, but also disrupt the normal market order, and ultimately seriously affect the social infrastructure and economic development. Therefore, through the development of culture to enhance the overall quality of social citizens and cultural and moral level is a must, to promote the outstanding Chinese culture, promote the comprehensive development of people, so that the economic development play a positive and positive role. Chinese socialist cultural market and cultural industry is the position of the construction of socialist spiritual civilization, responsible for the health and benefit through the cultural and artistic products and cultural and recreational activities to the broad masses of the people of socialism, collectivism, patriotism education, publicity the correct world view, outlook on life, values.

\section{Conclusion}

To sum up, the localization of Marxism in China and the development of the spirit of the Chinese nation are interdependent and mutually reinforcing, and they have the same identity and mutual promotion and complement each other. "The great cause of the need and will produce a noble spirit and the noble spirit of support and promote the development of great cause." Therefore, the Chinese Communists should carry forward and cultivate the spirit of the Chinese nation in different periods of historical development, highlight their characteristics of the times through different development themes, enrich the content of Marxism in China, and then promote the development of Marxism in China. The national spirit of the continuous sublimation, so the localization of Marxism in China and the modernization of the spirit of the Chinese nation must be regarded as a long-term historical task to the party's achievements to promote the Marxism in China and the national spirit of the promotion, and ultimately Localization of Marxism and Modernization of Chinese National Spirit.

\section{References}

[1] Selected Works of Marx and Engels: Volume 1, [M], Beijing: People's Publishing House, 1995.20-22

[2] Marx and Engels Complete Works: Volume 4, [M], Beijing: People's Publishing House, 1958.535-537

[3] Marx and Engels Complete Works: Volume 10, [M], Beijing: People's Publishing House, 1965.480-483

[4] Marx and Engels Complete Works: Volume 41, [M], Beijing: People's Publishing House, 1982.74-76

[5] Stalin Collection: Volume 2, [M], Beijing: People's Publishing House, 1955.293-294

[6] Lenin Complete Works: Volume 28, [M], Beijing: People's Publishing House, 1990.166-167 
[7] Selected Works of Mao Zedong: Volume 2, [M], Beijing: People's Publishing House, 1991.9,420,632,752 